Why entrepreneurs establish firms: Competition, protection costs, and rise of the firm

Kotorov, Radoslav P

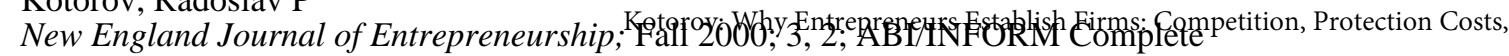
pg. 35

\title{
Why Entrepreneurs Establish Firms: Competition, Protection Costs, and Rise of the Firm
}

\author{
Radoslav P. Kotorov
}

Two theories have tended to dominate the discussion of the nature and function of the firm. The first views the firm in terms of the need to efficiently organize production; the second finds the key in the hypothesis that moving to the hierarchical structure of the firm can result in savings in transaction costs. This article presents an alternative perspective on the nature and function of the firm. The hierarchical organization proposed provides the entrepreneur with an important kind of protection -protection against the disadvantageous dissemination of competitively valuable information, which proprietary use contributes to the realization of profits.

Felicity is a continual progress of the desire from one object to another, the attaining of the former being still but the way to the latter. The cause whereof is that the object of man's desire is not to enjoy once only and for one instant of time, but to assure forever the way of his future desire. And therefore the voluntary actions and inclinations of all men tend, not only to the procuring, but also to the assuring of contented life; and differ only in the way, which arises partly from the diversity of passions in diverse men, and partly from the difference of the knowledge or opinion each one has of the causes which produce the effect desired.

\section{-Thomas Hobbes \\ Leviathan, Part I: Of Man}

I $\mathrm{n}$ the past few decades, two theories have tended to dominate the discussion of the nature and function of the firm. The first, whose lineage traces back to Adam Smith (1789), views the firm in terms of the need to efficiently organize production. The other, due to Coase (1937), finds the key in the hypothesis that moving to the hierarchical structure of the firm can result in savings in transaction costs. Both accounts have explanatory power when it comes to understanding how firms come into existence.

This article discusses the development of an alternative perspective on the nature and function of the firmcontributing to our understanding of what accounts for the emergence of firms. The kind of hierarchical organization associated with the firm-as an alternative to the nonhierarchical arrangements involved in ordinary market transac- tions-provides the entrepreneur with an important kind of protection. This is protection against the disadvantageous dissemination of competitively valuable information, which proprietary use contributes to the realization of profits.

If the entrepreneur is to break even and realize profits, the rate of dissemination of competitively valuable information, which in turn leads to imitation and thus intensifies competition, has to be lower than the rate of market penetration. Conversely, if the rate of dissemination of competitively valuable information is higher than the rate of entrepreneurial market penetration, incumbent firms will be able to take advantage of their established market positions, and the entrepreneur is likely to incur losses proportionate to his or her initial investment. To the extent to which the entrepreneur's marginal cost of controlling the dissemination of competitively valuable information is lower than his or her profit, the individual will be inclined to incur cost, call it a protection cost, to minimize the risk of not breaking even. In this aspect, the cost of hierarchical organization, which is one particular type of protection cost, is incurred because hierarchy offers some distinct advantages, which cannot be realized by simply using the intellectual property rights system.

This article begins with an explanation of the function of the entrepreneur in the economic system. It then discusses protection costs and their role, as well as the role of hierarchy in the entrepreneurial success.

\section{The Entrepreneur as a Newcomer on the Economic Scene}

The question of who the entrepreneur is and what he or she does has been a regular subject ever since the 18th century when Richard Cantillon (1931) introduced the term for the first time in the economic literature. Prior to Cantillon, sporadic descriptions of the entrepreneur are found in some 16th-century French texts, where the entrepreneur is described as a warrior, often compared to Hector and other Trojan warriors, intent to risk his life and fortune. This conception has its origins in the fact that many French entrepreneurs were settlers in the colonies in Florida. The English equivalent of the French entrepreneur was the undertaker and the merchant adventurer (Hoselitz 1960).

Cantillon defines the entrepreneur as a risk-taker, for he buys at a certain price and sells at an uncertain price. Later on, risk bearing was removed from the function of the entrepreneur on the grounds that all resources belonged to 
the capitalist/investor, and, as a result, two new conceptions of the entrepreneur emerged. Schumpeter (1936) defines the entrepreneur as an innovator, whose function is to introduce new goods, resources, and organizational forms in the economy. The alternative concept is that of the coordinator entrepreneur (Kirzner 1973; Casson 1982), who merely controls the flow of resources. ${ }^{1}$ Although both conceptions recognize the importance of the entrepreneurial valuable knowledge, i.e., innovation (Schumpeter 1936) or market information that is unknown to other market agents (Kirzner 1973), they fail to consider the role of the entrepreneur in coping with competition in the process of realizing profits from the possession of knowledge.

In trying to define the function of the entrepreneur, von Mises (1949) begins with the question of how the entrepreneur appears on the economic scene. Stated differently, Mises's question puts the focus on the ability of the entrepreneur to participate in market exchange, which in turn suggests that we have to look at (1) what are the valuable assets of the entrepreneur, and (2) how these valuable assets generate profit. According to Mises, the entrepreneur is a newcomer to the market, and since the market system is a positive sum game, in which some agents incur losses even though the overall benefits exceed the total amount of the losses, the entrepreneur is by definition an antagonist:

\begin{abstract}
What a newcomer who wants to defy the vested interest of the old established firms needs most is brains and ideas. If his project is fit to fill the most urgent of the unsatisfied needs of the consumers or to purvey them at a cheaper price than their old purveyors, he will succeed in spite of the much talked of bigness and power of the old firms. (Mises 1949, p. 276)
\end{abstract}

If the newcomer has to distinguish his or her business from incumbent firms to establish it at the market, then the function of the entrepreneur is to select a potentially profitable innovation, produce it, and sell it. These three elements are inseparable from the entrepreneurial function, because even if the entrepreneur uses agents to fulfill any one of them, he or she is still the responsible party for the success or failure of the venture. If any of these elements is delegated without the entrepreneur assuming responsibility for the success or failure of the venture, a moral hazard problem will arise, which will undermine the probability for success, and will likely drive capitalists/investors away from the venture. Innovation is a new or an improved way of satisfying wants, which is achieved either by providing the consumer with new or with cheaper goods. The choice of profitable innovation involves a judgment whether a product or a service is indeed wanted and whether it will be bought at a price greater than what it takes to produce it. From this perspective, the most valuable asset of the entrepreneur is the competitively valuable information he or she has about the commercial potential of some innovation or market opportunity in general.

When the entrepreneur discovers or acquires this valuable asset (i.e., the competitively valuable information), he or she has to decide how to bring it to market to realize a profit. Inherent in this endeavor is the risk that competition may eliminate the profit opportunity, and even cause losses if comparable products or services emerge and capture significant market share before the entrepreneur is able to establish his or her own products or services at the marketplace. Thus, the entrepreneurial dilemma is not simply what to produce and how much to produce, but also how to prevent the depletion of profits as a result of competition. ${ }^{2}$ In addition, the entrepreneur must determine what it will cost to prevent the innovation from (1) becoming common knowledge, and, (2) from being freely used if it does become common knowledge.

\section{Protection of Competitively Valuable Information}

Why is the protection of competitively valuable information important? The reason is found in certain core doctrines of the Austrian school of economics. First, markets inherently involve the rapid dissemination of information. Hayek (1937) metaphorically describes the market process as a relatively cheap communication network in which prices efficiently transmit signals about changing market conditions and changing use of resources, which in turn improves the decision-making and the coordination among producers. However, if prices convey information about changing market conditions, new products convey information about the causes of the changes in the market conditions and about the causes of resource relocation. In other words, new products reveal precisely why prices go up or down, why consumers switch from one product to another, and why investors redirect their capital. Second, profit is a residual left after all costs are subtracted from revenues, which competition tends to eliminate. As Schumpeter (1936) explains, cost competition strikes at the profit margins of firms and entrepreneurial competition strikes at the foundations of firms by making their products and services obsolete. In both cases profits decline. Combining these two points leads to the conclusion that markets, as distinct from hierarchies, disseminate competitively valuable information, which intensifies competition, and thus eliminates the source of profit.

Within the context of the Austrian understanding of markets, profits, and competition, the entrepreneurial penetration of the market (i.e., the ability to secure sufficient 
market share to break even and even realize profits), is contingent on the ability of the entrepreneur's competitors to adapt their market plans, given the available information about the cause of his or her success. In essence, the dissemination of information puts the entrepreneur and his or her competitors in what is known in decision and game theory as the hot dog stand case. According to the hot dog stand case, there is one highly successful hot dog stand located on Main Street. A potential competitor is contemplating penetrating the street market hot dogs. The entrepreneurial problem that the competitor has to solve is where to locate his own stand: as close to or far away from the existing hot dog stand? The most effective strategy to split the market is to locate the new hot dog stand next to or across from the existing one. Similarly, the more information competitors have about the entrepreneurial product or service, the easier it is to offer close substitutes. If the market opportunity upon which the entrepreneur acts is very appealing, the number of competitors is likely to be large, and, as more competitors enter the game, a crowding effect may occur. The latter is a situation where far too many profit-seeking agents pursue a single opportunity that cannot be realized by all of them. Consequently, some of the agents will fail to realize the opportunity and will incur losses proportionate to their investments. ${ }^{3}$

Given the role of markets in disseminating competitively valuable information and how dissemination causes profits to decline, it is reasonable to assume that rational and opportunity-minded individuals will seek to prevent or, at least, to delay the dissemination of their competitively valuable information. Making this information public and freely available is equivalent to the depletion of a profitable resource. Placing a product on the market, of course, involves the disclosure of competitively valuable information, leading to competitors trying to reverse engineer the product. Yet, the disclosure is still only partial, for the production process cannot always be inferred from the properties of the product. One product-design firm emphasized the importance of product information protection: "Awards [for products] make great wall hangings. Patents make great walls." (Business Week June 7,1999). Awards provide producers with high public visibility and thus can be an important factor in their marketing campaign and in securing name recognition. Yet, name recognition by itself is insufficient to sustain profits, which is why the entrepreneur has an interest in slowing the outflow of such information as much as possible. In fact, MIT's Sloan School of Management recently advertised a conference in which managers would learn how to "use 'barbed wire' approaches to protect new product investments." ${ }^{\text {"4 }}$ Moreover, since competitive advantage is secured not merely by the possession of product and service information, entrepreneurs and business managers are increasingly guarding their market plans, tactics, and other intangible sources of com- petitive advantage. For example, McKinsey Inc. says it "has developed techniques that are as well-guarded as they are successful" (Business Week April 12, 1999). And when this author recently suggested to an executive at the Dana Corporation to do a study of their (rather innovative) internal organizational structure, he was politely told that this involved proprietary information.

\section{Types of Protection Costs}

In a broad sense, protection costs are all costs incurred to reduce competitive uncertainty, which arises because competitors may take away some of the market share and profits that entrepreneurs expect and that established firms realize. The need for an established firm or a new market entrant to capture and maintain market share is determined by the fact that profit is a function of price and market share, and competition adversely affects both. The exclusive use of competitively valuable information significantly enhances the ability of the firm to capture and maintain a share of the market. Exclusivity arises either because of existing asymmetry between the knowledge base of one firm and its competitors or because of the firm's ability to use this knowledge proprietarily. Various degrees of asymmetry and proprietary use produce different degrees of protection as shown in Exhibit 1.

As can be seen from this exhibit, the more control an agent has over his or her competitively valuable information, the more likely it is that the agent will be able to capture a larger market share and sustain it over a longer period of time. Coca-Cola's secret formula is the paradigm case. Conversely, if an agent has less control over the dissemination and use of competitively valuable information, as is the case when competitive advantage is secured through the possession of marketing data only, more agents will try to enter and split the market with the incumbent agent.

Exhibit 1 also shows that competitive uncertainty arises either because the firm does not have information about its competitors, or because its competitively valuable information has become available to its competitors. Hence, protection costs will be incurred to prevent the occurrence of either one. The costs to reduce competitive uncertainty can be organized in a two-by-two matrix (Exhibit 2), in which the first dimension represents appropriability and sustainability costs, and the second dimension indicates whether the costs are incurred to protect product information or market share (Kotorov 2000).

Appropriability is an old concern, as old as the concept of property rights. In fact, John Locke's theory of property rights, according to which a person is entitled to the products of his labor (Locke 1988), is an appropriability theory, for rights are institutional devices that guarantee to owners the ability to appropriate by giving them the legal means to prevent others from obstructing the appropriation process. 


\begin{tabular}{|c|c|c|c|}
\hline \multicolumn{4}{|c|}{$\begin{array}{c}\text { Exhibit } 1 \\
\text { Taxonomy of Competitively Valuable Information }\end{array}$} \\
\hline \multirow{4}{*}{ Asymmetry } & \multicolumn{3}{|c|}{ Proprietary Use } \\
\hline & & High & Low \\
\hline & High & Trade secrets & $\begin{array}{c}\text { Employees' tacit } \\
\text { knowledge }\end{array}$ \\
\hline & Low & Patents & Marketing data \\
\hline
\end{tabular}

The cost to secure property rights in original acquisition, when property is not acquired from a previous owner, is a protection cost. Thus, the fee paid to obtain a patent is a protection cost to secure appropriability of competitively valuable information. On the other hand, the cost to transfer property title in derivative acquisitions is a transaction cost, for it is paid to execute a market exchange. This distinction is necessary in understanding the difference between protection and transaction costs, which will be useful in understanding the role of protection costs in the formation of hierarchical organizations ("firms"), as distinct from the decentralized market exchange between individual agents.

Sustainability is a modern concern. First, mass production showed that product life matters. The longer a product is sustained on the market, the higher the total return on the investment to produce it. Second, investment in fixed assets necessitated the continual existence of firms. If a firm is forced out of the market, investors find themselves owning either obsolete assets or assets whose liquidation value is less than the value of the going concern of a firm-if these assets are deployed in a successful business. Thus, protection costs are incurred both to extend product life, as is the cost to maintain trade secrets, and to maintain the continuity of the firm, as are research and development (R\&D) costs.
Certain expenditures offer varying degrees of protection. The degree of protection has impact on both price and market share, and thus is highly relevant to the choices of entrepreneurs and managers of firms. Complete protection, where it can be obtained, protects both the price and market share of the firm. Patent privileges in England prior to the adoption of the statute of monopolies in 1624 offered complete protection to patent holders. For they gave the patent holder 100 percent of the market share by preventing anyone else from producing substitutes or functionally similar products, even if alternative technologies could be developed. Since, in effect, such protection subverts the function of free markets, it was abandoned in favor of the more limited intellectual property protection that gives innovators protection against imitation but not against alternative, functionally similar innovations. Today, patents and trade secrets secure various degrees of protection depending on the complexity of the object of protection.

Partial protection can also impact favorably on either the price at which the firm can sell its product, its market share, or both. The resources expended to keep suppliers' information from competitors provides partial protection of the firm's pricing mechanism and thus helps to maintain its current price levels. The cost of trademarks, brand names, and advertising that promotes the firm's public image and thereby secures consumer loyalty are incurred to preserve

\begin{tabular}{|c|c|c|}
\hline \multicolumn{3}{|c|}{$\begin{array}{c}\text { Exhibit } 2 \\
\text { Taxonomy of Protection Costs }\end{array}$} \\
\hline & Product Information & Market Share \\
\hline Appropriability & $\begin{array}{l}\text { Patents, trade secrets, } \\
\text { know-how, etc. }\end{array}$ & $\begin{array}{l}\text { Brand advertising, } \\
\text { trademarks, etc. }\end{array}$ \\
\hline Sustainability & R\&D, strategic plans, etc. & Competitive intelligence \\
\hline
\end{tabular}


the firm's market share. ${ }^{5}$ The cost of R\&D are incurred to preserve the competitiveness of the firm in the future. Where relatively complete protection is the result of institutional arrangements, as is the case of patents, copyrights, trademarks, and other intangible assets, the protection costs tend to be low. On the other hand, the cost of partial protection can be very high, as is the case of brand-name and corporate-identity advertising.

Patents and brand-name advertising can be viewed as pure types of protection costs. If the protective function of patents is apparent, how brand-name advertising secures protection against competitive uncertainty requires explanation. Brand-name advertising expenditures are incurred to secure consumer loyalty. Since loyal customers do not switch immediately to better products, brand advertising buys firms time to respond to competitor's innovations by developing and introducing their own alternative innovations. Similar is the function of R\&D, as its role is not simply to find new products before competitors do, but also to develop alternative products shortly after competitors have introduced new products on the market to prevent a decline in market share and profits.

While it is hard to deny that brand-name advertising is a protection cost, one may object that $R \& D$ is on the grounds that if $R \& D$ provides protection against competitors, then it is hard to explain why firms often conduct joint R\&D projects or why firms form alliances and partnerships. Implicit in this objection is the notion that the entrepreneur can develop a fully decentralized business organization by using subcontractors, alliances, and partnerships. Certainly, it is true that firms share technical information. Nevertheless, careful analysis of joint R\&D projects reveals three distinct cases, two of which are essentially protective, while the third is purely cooperative but unintended consequences occur, which is why firms rarely enter into this type of arrangement. The first case is when firms cooperate to compete against a market dominant firm, such as the alliance between Netscape, Sun Microsystems, and AOL to counterbalance Microsoft's dominance in the software market. The second instance is when firms jointly develop technology but deploy it in different markets, in which case they are not true competitors.

In the third case, firms cooperate until technology is developed, but upon completion of the project return to market competition. The unintended result may be cutthroat competition as between Sony and JVC, who together developed home video technology but became fierce competitors to establish their own Betamax and VHS standards. ${ }^{6}$ The return from cooperation to market competition upon completion of the joint project creates incentives for the parties not to disclose fully their competitively valuable information with the intent to gain competitive advantage in the endgame. If alliances and partnerships create incentive problems for established firms, they make entrepreneurs even more vulnerable, especially when the partnership or the alliance is with a well-established firm that has the resources to quickly develop a competing business, if this is in its own interest. For instance, Salesforce.com found out that its technology partner and investor Oracle had started a similar business. Since Oracle executives were sitting on the board of Salesforce.com, they had direct access to information about the company's business model, strategy, and technology, and thus could develop a competing business model at less cost (Business Week July 17,2000 ). If the benefits from establishing a competing business exceed the benefits from being an investor and a technology partner, the partner has strong incentives to defect from the original agreement.

\section{Soaring Protection Costs}

To be sure, protection costs were not subject to more careful classification and scrutiny because they represented a small percentage of the expenditures of firms. The cost of a production plant was often so much larger than the cost of obtaining a patent, that the latter cost could be viewed as little more than a rounding error. Employee turnover also resulted in transaction costs associated with recruiting new employees that were very large in proportion to the costs of retaining key employees (i.e., those who could carry proprietary information with them). This situation has changed. Now there is excess both in production capacity and in venture capital, and computer networks have substantially reduced a wide range of transaction costs.

The first-mentioned development means that there has been a significant reduction in the importance of production costs as a barrier to entry on the market. Thus, imitation, substitution, and innovation have increased competition and shrunk the profit margins of firms. Correspondingly, the lowering of transaction costs has substantially reduced the ability of entrepreneurs and firms to reach out for talented employees through electronic data interchange (EDI) systems, which has forced incumbent firms to focus on retention. Similarly, the lowering of transaction costs has reduced the importance of product advertising as compared to brand-name and corporate advertising.

In contrast, expenditures devoted to protection are now sometimes very substantial. In 1989, Philip Morris spent over $\$ 2$ billion to maintain a portfolio of valuable brand names. McDonald's spent $\$ 424.8$ million on its trademark. The firms making up the Pharmaceutical Manufacturers Association spent $\$ 7.3$ billion on $R \& D$, and this was a full 16 percent of their total annual sales (Parr 1992). Recent estimates suggest that, due to increased economic espionage (itself the result of the growing globalization of markets), theft of trade secrets cost U.S. firms $\$ 1.8$ billion in 1992. Intellectual property theft rose by more than 300 percent from 1993 to 1995 , and the potential losses rose to $\$ 24$ billion annually. According to Peter Pitorri (1997, pp.32-33), 60 percent of the financial losses resulted from 
theft of strategic plans, R\&D, and manufacturing process information, and 75 percent of all incidents involved employees of the disadvantaged firm.

Protection and theft are both motivated by the profit opportunities inherent in competitively valuable information, which in many cases are substantial. For example, analysts estimated that Texas Instruments collected about $\$ 150$ million in royalties in 1989 . Moreover, this revenue is generated without Texas Instruments undertaking the risks of production and marketing the products based on the patented technologies. Furthermore, a recent dispute between Procter \& Gamble and Kimberly-Clark Corp. revealed that the two companies protect their positions on the $\$ 3.9$ billion-a-year diaper market with more than one thousand patents "covering everything from the amount of elastic around the legs to the Velcro tabs used as fasteners" (The Wall Street Journal April 5, 1999). It is not difficult to see that the cost to secure the protection of the $\$ 3.9$ billion market, which is the cost of maintaining a portfolio of related patents that are not used for production but rather to prevent competitors from using them, is far less than the cost of an insurance policy that protects an income-generating real estate property with the same value. On the other hand, precisely because the opportunities are so big and because functional identity with close substitute products is difficult to prove in court, firms are likely to infringe upon inventions despite the threat of high penalties. The expected benefits from the infringement are by far higher than the cost of litigation and the cost of settlement, especially when the petitioner does not have the same resources as the defender. Kodak was forced to pay $\$ 1$ billion to Polaroid for infringing on its patents for instant photography (Parr 1992), but it is doubtful that the cost of the litigation to prove the infringement could be afforded by any less powerful firm than Polaroid.

It remains to consider how protection costs contribute to an explanation of why firms come into existence. Network technology allows for the decentralization of production, but it also has made protection costs, if not more important, at least as important as transaction costs, when one considers whether to use the market mechanism or create a hierarchical organization. ${ }^{\text {? }}$

\section{Rise of the Firm}

Entrepreneurs create firms. This does not mean, however, that it suffices to think of the firm as simply the coincidental outcome of entrepreneurial activities, as Schumpeter seems to suggest: "In the normal case things so happen that entrepreneurial success embodies itself in the ownership of a business" (Schumpeter 1936, p.156). In contrast, R. H. Coase (1937) offers an explicitly causal hypothesis, namely that entrepreneurs establish hierarchical or "vertically" organized firms to reduce the transaction costs associated with using the "horizontal" contractual relations of the market to achieve production goals. The firm's hierarchical organization allows costly market negotiations to be replaced with internal governance directives, at significant savings in transaction costs.

Coase (1937) also concluded that changes such as the telephone and the telegraph, which tend to reduce the cost of organizing spatially, will tend to increase the size of the firm. There is a puzzle here, however. These technologies not only reduce the cost of organizing, which enables the firm to grow, but they also reduce the cost of transacting, which, according to the hypothesis, should increase the use of horizontal market mechanisms instead of hierarchical firms. As technological advances decrease the cost of transacting, one would expect that more entrepreneurs would shift from hiring more employees to subcontracting and outsourcing more and more functions of the firm (i.e., entrepreneurs would shift from organizing to pure coordination). Pure coordination is carried out entirely in a decentralized manner (i.e., in the absence of command). This would be expected, according to .Coase (1937), when choosing between organization and the price mechanism. In this instance, entrepreneurs compare two sets of costs: the cost of organizing $v$. the cost of using the market mechanism. ${ }^{8}$ From a Coasian perspective, one has to ask why there has not been much more decentralization of firms. ${ }^{9}$

A plausible explanation, is that market coordination, which can be cheaper today than hierarchy, is also the fastest mechanism for the dissemination of competitively valuable information. Indeed, firms have become much more spatially decentralized but, at the same time, their invisible boundaries are heavily protected by the firewalls of the firm's internal network. To the extent that the costs of using a market mechanism or hierarchy are comparable, the only relevant factor for having firms rather than markets is the development and protection of competitively valuable information. Even the earliest entrepreneurs were ready to protect their competitively valuable information by deploying hierarchical organization. For example, in 1717, Thomas Lombe opened the first factory in England. He used not only patents to protect the design of his machines, but also a centralized method of production, which gave him significant control over his employees. His centralized manufacturing method, which became known as the factory system, was in sharp contrast to the manufacturing method of the British merchant entrepreneurs who commissioned different households, similar to the modern method of outsourcing. Anecdotal evidence suggests that Lombe's motivation for strict control over his employees was due to the fact that he stole the design of his machines from Italian weavers. Aside from the anecdotal evidence, how exactly does this need to protect give rise to the kind of hierarchical organization that we call a firm?

First, an innovation can be common knowledge but may not be freely available. Patents are the most obvious exam- 
ple for they are publicly available for review, but their use is restricted exclusively to the patent holder. We have to distinguish two types of patentable innovations: (1) perfectly protected, and (2) partially protected inventions. The perfect and partial protections are properties of the invention and not of the legal system. Perfect protection means that no alternative product or method of production can be invented. This completely eliminates the possibility of competition. Partial protection occurs because technical problems can be solved in more than one way. ${ }^{10}$ Partial protection secures the exclusive use of a product or method, but does not preclude the possibility of competitive substitutes. For example, there are two methods for production of instant coffee: (1) using spraydryers to evaporate water from the extract, and (2) using freeze-dryers to sublimate water from the frozen extract. The end-product - instant coffee-is identical but is obtained in a completely different way. Thus, partial protection only raises the cost of entry for competitors who have to develop alternative products or methods.

If an entrepreneur has perfect protection either because he or she is also the inventor or has acquired the patent rights, he or she can outsource all functions without fear that the profit opportunity will be eliminated. Alternatively, the entrepreneur can license others to produce, and receive royalties in return. Licensing can be viewed as subcontracting someone else to organize the commercialization of innovation. On the other hand, if an entrepreneur has only imperfect protection, then outsourcing and subcontracting accelerate the dissemination of competitively valuable information, which may lead to the faster development of alternative solutions. By internalizing the production process, the entrepreneur can slow the dissemination of competitively valuable information. This, in turn, will hopefully give the entrepreneur more lead time to capture market share. In highly competitive markets, such as the computer market, even a minute delay in the dissemination of competitively valuable information can offer serious advantages. As Stinchcombe (1990) points out, IBM's monopoly advantages in the late 1980s, when the federal antitrust commission was considering taking action against IBM, could have been easily eliminated if IBM had been forced to release its competitively valuable information to other firms at the same time as it released it to its own production units.

Second, if an innovation cannot be afforded legal protection through patents, the entrepreneur can still endeavor to keep the essentials secret. Such is the case with many formulas, such as the one for making Coca-Cola. The secret can be preserved only if access to it is restricted. In this sense, a trade secret"1 is a kind of self-administered property right, for whether it is enforceable depends on the care that the agent takes to prevent its disclosure. Under this condition, both outsourcing and subcontracting involve a much greater risk of the disclosure of the secret. Again, by internalizing the production process, the entre- preneur can better maintain the proprietary status of his or her valuable information.

Third, there are innovations that are perfectly unprotected. Market information is a clear example of perfectly unprotected information. The only way to profit from its possession is to realize a first-mover advantage. Suppose an entrepreneur discovers a new market opportunity, such as the delivery of a foreign product to a local market. As soon as the product is delivered, the opportunity is completely disclosed and others can take advantage of it, provided there are enough foreign suppliers so that the first entrepreneur cannot have exclusive distribution rights. Under these conditions, it will be difficult for the entrepreneur to subcontract any services, such as shipping, packaging, etc., without disclosing the opportunity. Thus, it is very likely that the entrepreneur will internalize the key functions of his or her business to prevent the disclosure of the opportunity until the moment when he or she actually takes advantage of it. Where the business organization itself is the valuable entrepreneurial asset, the solution to the problem is still the same. Internalizing as many essential functions as possible has the effect of limiting the dissemination to within the boundaries of the firm. ${ }^{12}$

A fourth consideration is that by internalizing the production and transactions, the entrepreneur not only prevents the dissemination of competitively valuable information, but also becomes the owner of the information that is created in the process of the development of the original idea. Most innovations are not only imperfectly protected, but also are subject to an open-ended process of improvement. Subcontracting and outsourcing does not prevent this process of improvement from going forward, but it creates the problem that others can now lay claim to the ownership of these new innovations, while the employment relationship does not.

In The Wealth of the Nations, Adam Smith (1937) describes the accidental invention of a mechanism to open the valves of the first fire engine. This significant improvement in the operation of the fire engine was inspired by the desire of the worker not to perform the task he was assigned to perform (i.e., to open and shut the communication between the boiler and the cylinder of the fire engine). The inventor was a boy who preferred to play with the other boys at work. He had neither education nor training in machine design, but was clever enough to conceive that, by tying a string from the handle of the valve to another part of the machine, his job would be fully automated. If the boy became the owner of this invention, his slight and unintentional but cost-effective improvement could force the producer of the fire engine out of the market. Since production requires planning, investment, and risk taking, it is natural for producers to try to prevent the ownership of improvements to lead to the appropriation of the original product. Consequently, confidentiality and transfer of own- 
ership of the improvements to the employer have become standard clauses in employment contracts. But why can such clauses not be incorporated in subcontracting agreements?

Because hierarchy involves monitoring costs (Alchian and Demsetz 1972) and is thus expensive. It can be expected that decentralization supplemented by the right contracts eliminate both production and protection inefficiencies. Indeed, in addition to confidentiality agreements, two other types of contracts have evolved historically to secure entrepreneurs and firms the appropriation of improvements made by their subcontractors: (1) grantback agreements, and (2) compulsory cross-licensing agreements of derivative patents. The fact that these contracts unconditionally transfer the ownership of any derivative innovations, which are the most important source of competitive advantage for firms, raises some concerns about how far the causal chain can extend. The European Community and Japan have taken the stand that technology developers, licensees, and subcontractors cannot be obliged to assign to the original contractors and licensors the rights in patents for improvements (Ordover 1991). The assumption is that developers of technology have their own interests to protect and that the unlimited assignment of derivative innovations to the procuring firm deprives them of competitive advantage.

If we use Schumpeter's famous antagonists-the horse coach producers and the automobile manufacturers-the issue about the ownership of derivative innovations boils down to whether the horse coach producers should own the invention of the automobile just because both have four wheels. The U.S. antitrust committee is also examining whether open-book subcontracting, which allows the procuring firm to go deep into the blue books of their subcontractors, is not violating antitrust laws because it deprives the subcontractor not only of competitive capabilities but also of decision-making abilities. For instance, Cisco not only requires its subcontractors to open their blue books completely, but it also sets their production and profit goals, which is only natural, given that Cisco has complete information about them. Once institutional obstacles are created for complete contractual protection, many information-related problems emerge and force firms to integrate processes internally. ${ }^{13}$ Thus, internalization of production and transaction processes, especially with respect to R\&D work, provides the only way to prevent the dilution of ownership of the original idea.

\section{Benefits from the New Theory and Future Research}

With so many theories of entrepreneurship and the firm already existing, one may ask what are the benefits from the one proposed here? The answer requires that one start by considering that neither the production nor the transaction cost theory of the firm manage to capture certain essential features of firms. Both theories view the firm from the perspective of a static theory or organization, and against the background assumption of complete information, in which the behavior of other firms can be taken as a given. But firms are dynamic organizations operating over time, and as Knight (1921) explains, they do so under conditions of pervasive uncertainty and strategic interdependence. The behavior of any given firm in the marketplace depends critically on what it believes other firms will do. But this interdependency undermines the notion that each firm can proceed as if the behavior of other firms is given. If the firm is merely an independent production device, and information is complete, then a given firm can settle on a unique level of output. Under this model, there is no uncertainty and profit maximization is a matter of simple computation. In addition, there is no room for entrepreneurial activity or for surprise. On the other hand, by taking these into consideration, we expect the focus of future research to not be on analytical models but rather on microstrategies, the study and teaching of which will enhance the entrepreneur's chances to succeed in the competitive market.

Perhaps the most frequently cited empirical evidence for the inadequacy of the static theories is that they predict "unequivocally that a profit-maximizing firm in a perfectly competitive market will not advertise" (Blaug 1992). The lack of incentives for advertising is explained in terms of the perfect elasticity of the demand curve, which guarantees that the firm will sell all it produces at some price or other. But, in reality, just the opposite happens. Entrepreneurs advertise to realize strategic goals. For example, in its formative stages $A O L$ engaged in a very expensive advertising campaign both to realize a firstmover advantage and to deter competitors from entering the market, and it asked the IRS to treat the cost as an investment rather than an expense. In more general terms, the static models are unrealistic because they fail to take into account the future. Such a static model is built on the basis of historic costs from which little can be extrapolated about the future. Past production and transaction costs tell us nothing about innovation, which is the source of future profits.

Protection costs, unlike the other two types of costsproduction and transactions costs-are incurred with an eye to paving the way to the future, to making the future less uncertain. To recognize the need to incur protection cost, is to recognize that (1) current profits are contingent on the ability of the firm to develop its market share before the emergence of competition that will eliminate its profits, and that (2) future profits are contingent on the ability of the firm to continuously innovate to open new profit opportunities as old ones are closed out. In this sense, protection costs are incurred to secure the continued existence of the 
firm over time, and their study will provide entrepreneurs with the knowledge to develop sustainable enterprises.

Finally, special emphasis should be put on the relevance of protection costs in understanding the firm as a dynamic organization. Why, then, not compare the present view with dynamic competence-based theories of the firm? The lineage of the competence-based theories of the firm can be traced back not only to Adam Smith, but also to F. Knight (1921), and thus they take into account both division of labor and pervasive uncertainty. In fact, accumulation of resources and development of capabilities is viewed as a means to cope with market uncertainty (Penrose 1959; Richardson 1972; Chandler 1990). Certainly, it will be beneficial to analyze the role of protection costs within the context of these theories, especially as they apply to large-scale firms, ${ }^{14}$ but the scope of this article is limited to the impact of protection costs on the entrepreneurial actions. In this aspect, static theories provide a better reference point to see how the entrepreneur makes organizational decisions given certain initial conditions. In the production theory, the entrepreneur's organizational choices are constrained by the set of produc tion possibilities. Transaction costs, on the other hand, provide the entrepreneur with the means to choose cost-effective organization. In comparison, protection costs help the entrepreneur to choose organization that reduces competitive uncertainty, and since the protection extends over time, the protection costs pave the way into the future. Even though these three organizational consideration are analytically separable, it is likely that, in reality, they operate more or less together.

\section{Conclusions}

This article has argued that firms may come into existence as a result of the desire of entrepreneurs to protect competitively valuable information, which is the source of entrepreneurial profit. More generally, established firms can be viewed as private institutions that protect the value of industrial property in the process of competitive introduction of innovations. The market is a mechanism for the dissemination of information and, as such, it eliminates profit opportunities. The hierarchical structure of the firm can be employed to slow this process. The cost of hierarchical organization is a protection cost that the entrepreneur pays to keep secret his or her competitively valuable information from competitors. This and other protection costs were obscure because high production costs and high transaction costs were sufficient barriers to entry, and thus ensured the temporary existence of a profit opportunity. As the relative importance of production and transaction costs has declined, one can much better appreciate the importance of protection costs.

\section{Endnotes}

1. Hans Landstrom (1999) offers a detailed discussion of the different theories of entrepreneurship.

2. To try to preserve the profit is not the same as to try to obtain a monopoly position. Profit is not the same as monopoly rents. Thus, the protective actions of the entrepreneur only guarantee that he or she will realize profit and not that he or she will be a monopolist. The detailed treatment of this issue, which is closely related to the careful evaluation of the entrepreneurial risks, is out of the scope of this article.

3. The crowding effect is a special case of auctions with optimistic bidding in which an agent bids for resources with uncertain value. The winner in such auctions is the most optimistic bidder, but he or she is also running the risk that the resource may be significantly less valuable than expected. The latter situation is known as the winners' curse.

4. The quotation is taken from a brochure about a two-day program for senior technical and corporate managers on Developing \& Managing A Successful Technology \& Product Strategy organized by MIT's Sloan School of Management and to be held in June 21-22, 1999.

\section{Advertising campaigns that only inform the public about the product can be viewed as transaction costs.}

6. S. Scotcher (1991) cites research findings that the incentives of the parties to cooperate in joint R\&D projects depend partly on whether they can collude in using the result cooperatively.

7. There is a growing concern among scholars that transaction costs cannot account entirely for the emergence of hierarchy. Moreover, some authors have expressed the intuition that not all transaction costs are an obstacle for exchange and change. For instance, Moran and Ghoshal (1999) state that "some costs for certain transactions may actually be useful in helping actors initiate some productive institutional changes." The overgeneralization of the term "transaction costs" leads not only to failure to distinguish these other cost categories, but also weakens the explanatory power of transaction cost theory. 


\section{See Coase (1937) footnote 31.}

9. Interestingly, networking technology was developed in 1969 by the U.S. Defense Department Advanced Research Projects Agency (DARPA) to decentralize the control of the military and thereby prevent a Russian takeover of command and control in the event of war (see Castells, 1998, p. 7)

10. The conceptualization of this situation dates all the way back to 1654 , when Sir Christopher Wren characterized this as the principle of multiple solutions to a single problem.

11. Arrow (1971) has pointed that there is a fundamental paradox in the market of information. Information cannot be bought unless it is disclosed and if it is disclosed its value is reduced to zero. Trade secret property rights are the perfect example of this paradox for they are enforceable for as long as the secret is not revealed. If the secret leaks out in a legally permissible way the right is lost and the secret can be used by anyone.

12. Recently, U.S. Patent $5,799,286$ was granted to Electronic Data Systems Corporation for an Automated ActivityBased Management System. This means that some organizational and business methods can be patented However, this is a departure from the traditional legal doctrine about patents and is still highly controversial procedure. Business models come very close to being perfectly protected, and thus they may deter competition in general.

13. G. B. Richardson (1972) provides an explanation of why licensing of technology, for example, does not work First, knowledge is a special commodity that can easily become a free good. Hence, scarcity has to be created artificially and the function of patent laws is exactly this. A problem arises when the licensor sells rights at a fixed cost to a licensee but retains rights to manufacture the product himself. Because of the existence of fixed costs, unrestrained competition would drive prices below costs. The problem is not eliminated when licensing cost is converted to variable cost (i.e., when a fee is charged per item). In this case, the licensor can lower his or her own cost up to the amount of the royalty. Third, the licensor can license the product to others. Hence, the only solution is price fixing or market-sharing contracts, which, in fact, diminishes competition. Similar to the problems of licensing are the problems with the sale of existing technology. Even though the seller may assign his or her patent exclusively to one owner, he or she may sell alternatives to other firms. On a number of occasions, T. A. Edison developed and sold functionally similar technologies to competing firms, which is a reason why firms prefer to internalize the development of key technologies.

14. The issue about the relationship between capabilities and protection costs becomes very complex when considered in the context of a large firm. Development of core capabilities and strong commitment to the core may, in fact, constrain the firm. For instance, if Nokia did not change its core capabilities, it would have remained a small lumber manufacturer and not the global telephone giant. I have argued in different places that departure from core capabilities is a consequence of the function of the firm to protect market share and profits.

\section{References}

_April 5, 1999. Stopping Diaper Leaks Can Be Nasty Business, P\&G Shows Its Rivals. The Wall Street Journal.

-July 17, 2000. The Dark Side of the Valley. Business Week.

Akerloff, G. 1970. The Market for "Lemons": Qualitative Uncertainty and the Market Mechanism, Quarterly Journal of Economics 84 (August): 488-500.

Alchian, A., and Demsetz, H. 1972. Production, information costs and economic organization. American Economic Review, 62, 777-795.

Arrow, K. J. 1971. Essays in the Theory of Risk-Bearing. Markham.

Blaug, M. 1992. The Methodology of Economics. Cambridge University Press.

44 NEW ENGLAND JOURNAL OF ENTREPRENEURSHIP 
Cantillon, R. 1931. Essai Sur La Nature Du Commerce En General, translated by Henry Higgs, C. B. Macmillan Publishing Company.

Casson, M. 1982. The Entrepreneur: An Economic Theory. Martin Robinson.

Castells, M. 1998. The Rise of the Networking Society. Blackwell Publishers.

Chandler, A. D. 1962. Strategy and Structure: Chapters in the History of the American Business. Harvard University Press.

Chandler, A. D. 1990. Scale and Scope. Belknap Press.

Chandler, A. D. 1992. Organizational capabilities and the economic history of the industrial enterprise. Journal of Economic Perspectives, 6, 79-100.

Coase, R. H. 1937. The Nature of the Firm. Economica.

Echikson, W., and D. Rocks. July 5, 1999. The Name Coke Now Scares People. Business Week.

Hayek, F. A. von. 1937. Economics and Knowledge. Economica IV: 33-54.

Hobbes, T. 1668, 1958. Leviathan with introduction by H.W. Schnider. The Bobbs-Merrill Company, Inc.

Hoselitz, B. F. 1960. The early history of entrepreneurial theory. In Spengler, J. J., and Allen, W. R., (eds.) Assays in economic thought. Rand McNally and Company.

Kirzner, I. 1973. Competition and Entrepreneurship. The University of Chicago Press.

Knight, F. 1921. Risk, Uncertainty and Profit, University of Chicago Press.

Kotorov, R. P. 2000. Virtual Organization: Conceptual Analysis of the Limits of its Decentralization. Knowledge and Process Management, 8, 1.

Landstrom, H. 1999. The Roots of Entrepreneurship Research. New England Journal of Entrepreneurship, 2,2. pp. 9-20.

Locke, John. 1988 Two Treatises of Civil Government. Ed. Peter Laslett. Cambridge: Cambridge University Press.

Mises, L. von.1949, 1966. Human Action: A Treatise on Economics, 3rd Revised Edition. Chicago: Contemporary Books, inc.

Moran, P., and Ghoshal, S. 1999. Markets, Firms, and the Process of Economic Development. Academy of Management Review, 24, 3. pp. 390-412.

Ordover, J. A. 1991. Interfirm competition and collaboration. In M. Scott-Morton, (Ed.). The corporation of the 1990s: Information technology and organizational transformation. Oxford: Oxford University Press.

Parr, R. L. 1992. Investing in Intangible Assets. John Wiley and Sons, Inc.

Penrose, E. 1959. The Theory of the Growth of the Firm. Basil Blackwell.

Pittori, P. 1997. Counterespionage for American Business. Butterworth-Heinemann.

Richardson, G. B. 1972. The Organization of Industry. Economic Journal, 82, 883-96. 
Schumpeter, J. A. 1936. The Theory of Economic Development. Harvard University Press.

Schumpeter, J. A. 1942. Capitalism, Socialism and Democracy. New York: Harper and Brothers Publishers

Scotchmer, S. 1991. Standing on the Shoulders of Giants: Cumulative Research and the Patent Law. Journal of Economic Perspectives 5(1), Winter, 43-60.

Smith, Adam. 1937. The Wealth of Nations. New York: Random House Inc.

Stinchcombe, A. L. 1990. Information and Organizations. University of California Press.

Williamson, O. 1985. The Economic Institutions of Capitalism. New York: Free Press.

Radoslav P. Kotorov is a strategy consultant and director of research at M. F. Smith \& Associates Inc., Morristown, New Jersey, where he specializes in competitive strategy, emerging technologies and new business models, and knowledge management. He has a doctoral degree from Bowling Green State University, where he studied innovation, entrepreneurship, and theories of the firm. From 1994 to 1999 , Dr. Kotorov was the chief financial officer of a highly entrepreneurial chain of coffee shops in Ohio. His prior achievements include the establishment of the first private publishing house in Bulgaria in 1987 and the first credit card system in Bulgaria in 1990. He is also an experienced inventor and holds two U.S. patents. 